\title{
Modelling the Drivers of Impulsive Buying Behaviour: A Case of South Africa
}

\author{
Elizabeth Chinomona*, Mosidi Elizabeth Montso \\ Vaal University of Technology, Vanderbijlpark, South Africa \\ chakubvaelizabeth@gmail.com
}

\begin{abstract}
Impulsive buying behavior is an emerging phenomenon in marketing literature and it affects consumers across the board. Impulsive buying is seen as the outcome of demonstrative reactions that breed the unexpected craving to purchase. Impulsive buying is becoming an important factor for retailers since they generate a lot of income through this kind of behavior. Due to the expansion of organized retail over the country, shops are trying to comprehend the buying behavior of consumers and try by all means that they trigger consumers to act in an impulsive way. Traditional buying behavior of consumers was seen as when purchasers made a list for purchasing products then depart to a particular store and purchase it. But now the whole buying behavior is changing due to the rise in the income level of consumers. This is giving the consumers more buying power, transformation in the socio-cultural environment way of life and consumption pattern. This, therefore, influences the consumer to act in an irrational manner which is known as unplanned buying without considering the potential consequences which may include non-usage of the product, negative economic consequences and feelings of regret, fury and fault. So the present study aims to analyze how uniqueness, price and past orientation influence impulse buying behavior are focusing on classical clothing brands like Nike, Adidas and Reebok. This study attempts to discern how consumer's traditional planned shopping behavior is shifting to impulse buying behavior. The study used a quantitative research method and analyzed the data by means of SMART PLS to test the relationships and the model. 350 questionnaires were used for data analysis using convenience sampling process. The outcomes of the research showed a progressive and significant association between the predictors (the need for uniqueness, price and past orientation) and the outcome variable (impulsive buying behavior).
\end{abstract}

Keywords: Impulsive buying behaviour; need for uniqueness; price; past orientation.

\section{Introduction}

A number of factors which influence impulsive buying behavior have been discovered which include gender, race, age, marital status, materialism and psychological factors status but this study focused on the influence of need for uniqueness, price and past orientation on the impulsive buying behavior of the consumer. Items were disseminated to consumers in the Gauteng province of South Africa. According to Wu and Lee, (2016:1091), "consumer decision-making styles for goods differ according to consumers' cultural orientation and that consumer behavior can be predicted from an understanding of the cultural personality of consumers". Accordingly, goods and services can be better designed to meet consumer needs (Bharwada 2010; Rootman \& Kruger, 2017). The study seeks to enquire if need for uniqueness, price and past orientation contributed to consumers impulsive buying behavior. Thus, according to Goldsmith, Clark and Goldsmith (2006:411), it is said that individuals with increased requisite for uniqueness view high resemblance with others as unfriendly, and often attempt to make themselves different from others. Whereas with regard to price it can be seen that promotions are a way of framing purchasing decisions in the sense that paybacks received by consumers from the promotion are continual.

However, Yanga, Zhaob, Louc and Weia, (2013) say past orientation has an effect on most individuals because it either gives them desire to think about their past or enjoy stories about how things used to be in the "good old times". According to Janakiraman, Meyer and Morales, (2006:362), "'one effect of unexpected price discounts is that of causing a generalized affective effect on consumers", while Wu and Lee (2016:1093) that "negative affect induced by unexpected price hikes might suppress spending by limiting purchase consideration of other goods, while the positive effect induced by unexpected price drops might increase spending by expanding consideration of other goods". Therefore, unexpected cheaper prices, discounts, sales or specials play a major role on impulse buying of consumers. Past ways of working provided a comfort zone; persons who are past orientated become so comfortable in their memories that they falter to attempt new things, thus act impulsively. According to Hodgins and Amy, (2009), individuals with past orientation have a stout craving for instant gratification and partake lower self-control to postpone their indulgence to a future 
period. Thus, they do not think about the long-term. Implications of their actions and ardent on current stimulation through consumption while Baumeister, (2014:672) states that "when consumers are not able to resist current temptations and seek immediate pleasure they tend to act impulsively and have little selfcontrol". Park, Kim and Forney (2017:433) classified impulsive buying as four types which include "planned impulsive buying, reminded impulsive buying, fashion-oriented impulsive buying and pure impulsive buying". Zhang, Xu, Zho and Yu, (2018:522) added that there are "four categories of impulsive buying which include pure impulsive buying, reminder impulsive buying, and suggestion impulsive buying and planned impulsive buying" which is more or less the same with what Park, Kim and Forney, (2017) postulated. "Pure impulsive buying is the truly impulsive buying behavior where consumers break their normal buying pattern to make a novelty purchase immediately. Reminder impulsive buying requires the recall of one's prior experience or knowledge about products and cognitive effort will be needed in the process. Suggestion impulsive occurs when a consumer sees a new product and imagines a need for it. Compared with pure impulsive purchasing, suggestion impulsive buying may be an entirely relational process than an emotional reaction (Stern, 1962:33). Planned impulsive ordering is partially "planned" and refers that consumers are open to make purchases beyond shopping goals and search for any promotions.

Problem Statement: Impulsive buying has become a problem for the whole world (Zhang \& Kim 2013; Sunil \& Kesari, 2018). According to Burgess, (2003), Huang and Kuai, (2006) and Park et al. (2017) consumers are more impulsive than price conscious. This means that consumers do not care much about the price of products when it comes to buy what they want and this has a serious psychological and social consequence. Park and Park, (2015) said that impulsive buying behavior is characterized by two factors which are the stimulus of marketing (such as advertisement and promotion) and the time of the purchase. Impulsive buying behavior is a big problem in South Africa because people just buy classical clothes without planning and thinking leaving out other essential and critical things at home like food, rent and school fees for children (Venter de Villiers, Ca \& Chuchu 2018; Dhurup \& Tusiime, 2011).

This study singled out the need for uniqueness, price and past orientation as factors that lead to impulsive buying behavior in South Africa. These factors drive consumers to buy products impulsively disregarding the consequences. It seems that there is a lacuna regarding the factors that lead to impulsive buying behavior besides gender, age and marital status (Bakewell \& Mitchell 2009; Zhang \& Kim, 2013). Therefore, the contemporary research will try to fill this lacuna by bringing more knowledge on the fairly new variables such as need for uniqueness, price and past orientation on impulsive buying. This study will provide a new view on impulsive buying behavior based on these variables.

\section{Literature Review}

Four major aspects of this paper which include impulsive buying behaviour, need for uniqueness, price and past orientation are outlined and elaborated in this section.

Need for Uniqueness: Consumers of today aspire to be unique and different; that's why they indulge in impulsive buying when they see brands like Nike or Adidas on promotions or being advertised. Belk and Malhotra, (2013) and Lee, Ho and Wu (2018:79) noted that "product personality offers a mechanism for expressing one's actual self, ideal self, or social self and reflects one's own personality". Amaldoos and Jain, (2005) states that make with robust character tends to contain exclusive styles in product design which may differ itself from other contestant makes. However, Burns and Homer (2014:10) say "need for uniqueness individuals seek non-traditional and self-differentiating products such as scarce or limited versions of products, or even niche products, which are deemed as superior tools for demonstrating self-image". Tian, Bearden and Hunter, (2011:51) define purchaser's need for distinctiveness as "the trait of pursuing differences relative to others through the acquisition, utilization and disposition of consumer goods for the purpose of developing and enhancing one's self-image and social image". According to Aaker, (2013), need for uniqueness is human characteristics associated with a specific brand. Gwinner and Eaton, (2012) say the need for uniqueness naturally is regarded as one of the marketing tools to build an overall carbon copy appealing to targeted viewers. 
According to Knight and Kim, (2007:270), "new products or brands can be acquired more rapidly by purchasers who have greater demand of distinction than those having that demand at a lower level". Since consumer's need for uniqueness is anticipated to have a direct impact on the hedonic purchase, this acts as a mediator role in the relationship between consumer's need for exceptionality and impulse buying behavior. Netemeyer, Krishnan, Pulling, Wang, Yagci, Dean and Wirth, (2015:210), alleged that product rareness is defined "as the degree to which customers feel the brands are different from competing brands and how distinctive it is relative to competitors". Another antecedent of compulsive buying behavior according to Steenkamp, Batra and Alden, (2015) is made stature which refers to the relatively high status of product positioning associated with a brand.

Lastly, Zeithaml, Berry and Parasuraman, (2015) states that another antecedent of compulsive buying behavior can be professed significance which is the customer's overall assessment of the utility of a product or service based on perceptions of what is received and what is given. Avoidance of similarity according to Fisher and Price, (2014:477) refers to the "loss of interest in, or discontinued use of, possessions that become commonplace in order to move away from the norm and reestablish one's differentness". However, creative choice counter conformity according to Kron, (2014:9) "reflects one's personal style in material displays as accomplished through the purchase of original, novel, or unique consumer goods or via the decorative collection, arrangement and display of goods". South African market is budding into a pool of customers hungry for international brands superfluity fashion goods which they see as a symbol of success, wealth and status (Zhang \& Kim 2013; Lang \& Armstrong, 2018; Raisanen, Bjork, Lonnstrom \& Jauffret, 2018).

Price: Research by Kim and Kramer, (2006:311) found that "price discount based on percentage played a positive impact on consumer novelty perceived savings and purchase intention, that is, the more innovative in the form of price discounts, the more savings and purchase intention consumer would feel". However, Syam, Ruan and Hess, (2005) and Jaehyeon and Jaehyeon, (2016) found that customisation shows a vital role in changing the competitive situation like putting downward pressure on a competitor's prices. According to Schindler, (2012) fee is the quantity of payment or compensation given by one party to another in return for goods or services. The price is set so as to equate the quantity being supplied and that being demanded. According to Huang and Chen, (2013) and Lindblom, Lindblom and Wechtler, (2018), for planned purchasers, external reference price has no significant impact on impulsive buying decision, but as for unplanned purchasers, external reference price will have a significant impact on the purchase decision. Retailers also frequently use price discount offer strategy for promoting sales (Babbie, 2010; Hoch \& Loewenstein, 2016; Ayub \& Zafar 2018). Therefore, the price is multi-dimension (dependability) as well as one-dimensional (not dependable) as compared to impulsive buying behavior. Lower prices mean a better deal for consumers and force them to indulge in impulsive buying behavior without planning (Graciola, Toni, Lima \& Milan, 2018; Loureiro \& Breazeale, 2018).

Past Orientation: Zimbardo and John, (2008) argued that the previous habits of operational provide a comfort zone, hence, these individuals hesitate to try new things by acting impulsively. Baumeister, (2014) and Liang, (2012) proposed when people are in the habit of doing something, they are more likely to stick to their existing routines and are less likely to be impulsive. However, Raju (2012:272) says "shoppers with a strong past orientation are rigid; they are likely to be less risk-taking and less likely to act spontaneously/impulsively". Therefore, he argued that past-oriented people are less likely to be impulsive and more likely to be prudent. According to Zimbardo and John (2008), individuals who are historical oriented are those that are comfortable in their memories and set ways of the past. Holbrook, (2012) proved people who are highly nostalgic have a preference for products and services that remind them of the past, as that gives them comfort.

Similarly, Cotte, Ratneshwar and Mick, (2012) define people who are past orientated as those that are nostalgic, dodge new or unfamiliar leisure activities and prefer doing familiar activities that they grew up with. Since Zimbardo and John, (2008) stated that persons are past-oriented are comfortable in their memories and set of ways in doing things, hence, it is less likely for them to be impulsive and more likely to be prudent. People who are past-oriented are comfortable in their memories, factors such as nostalgia, rituals, traditions and memories of exactly how things used to be done in the good old days, play a major role for them not to behave impulsively. The study shows that persons who are past-oriented have little self-control 
and can surrender to immediate temptation. Furthermore, Baumeister, (2014) states that practicality or selfdiscipline is character's long-term preference for monitoring.

Impulsive Buying Behavior: Mcinnes and Price, (2012) say spending might be more important than actual product attainment since it can provide a highly pleasurable buying experience. According to Sherry, (2012) and Sunil and Kesari, (2017), accidental perusing or spending may sometimes be more important than actual product acquisition since it can provide a highly pleasurable buying experience for consumers. Furthermore, according to Watson, Clark and Tellegen, (2012) positive affect makes the individual sense enthusiastic, energetic, and vigilant, meaning that, high constructive affect involves a state of high energy, full concentration and pleasant engagement. Hoch and Lowenstein (2016) and Zhang et al. (2018) clarified thoughtless purchasing behavior as a struggle between the psychological forces of desires and willpower. While Kacen and Lee (2016) defined impulsive buying as unplanned buying with rapids decision making and a subjective bias in the form of immediate possession. However, Rook and Fisher (2016:189) defined impulsive buying "as consumer tendency to buy spontaneously, unreflectively, immediately and kinetically". Liang, (2012) and Bakewell and Mitchell (2009) concluded that spontaneous buying behavior is considered irrational, immature and highly risky since the buyer buys without consciousness and it's unplanned. Dittmar (2005), Wu and Lee (2016) and Sunil and Kesari, (2018) postulated that cost is one other factor that influences impulsive buying behavior.

Tendai and Crispen (2009:102) advocated that "the in-store shopping environment is a very important determinant of impulsive buying with factors such as in-store background music, store display, scent, in stock promotions, prices, shop cleanliness, shop density and store personnel all make up the in-store shopping environment". Rook and Hoch (2012) recommended a psychological model of buyer instinct buying behavior and proved out that impulse buying is characterized by the following five elements which are a sudden and spontaneous desire to act, a state of psychological disequilibrium, the onset of psychological conflict and struggle, a reduction in cognitive evaluation and lack of regard for the consequences of impulse buying behavior. Weinberg and Gottwald (2012) and Thoumrungroje (2018) indicated that impetuous buyers typically show greater feelings of amusement, delight, enthusiasm and joy. Hence, realistically to take an emotional variable as the predictor of an impulse purchase. According to Donthu and Gilliland (2010) and Chebad, Michon, Haj-Salem and Oliveira (2014), it is shown that customers with optimistic mood state exhibit higher risk-seeking propensity, and thus tend to engage in impulse behavior. Impulsiveness, whereas Puri (2012) says cautious people evaluate the implications of their actions and behave less impulsively.

The Conceptual Model: Portraying from the literature review, research model is conceptualised. Theorised associations between research constructs are then developed. In the conceptualised research model, need for uniqueness, price and past orientation are proposed as predictors (independent variables) of impulsive buying. Impulsive buying equals ending variable (dependent variable). Figure 1 illustrates this research model.

Figure 1: Model and Hypothesised Relationships

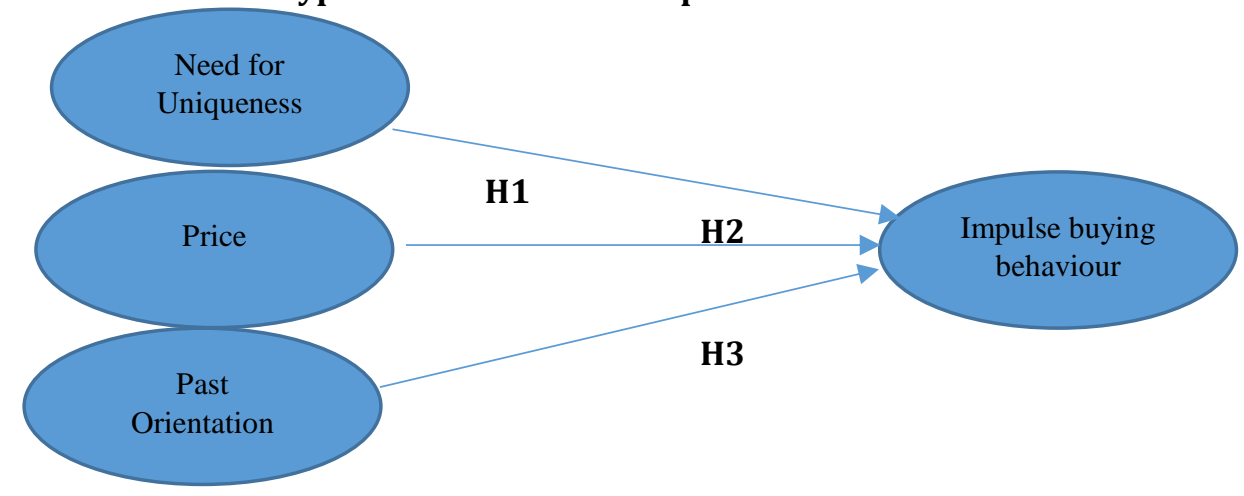

Source: Own Source

Hypothesis One: Positive relationship exists concerning need for uniqueness and impulse buying behavior. 
Hypothesis Two: Constructive connection is between price and impulse buying behavior.

Hypothesis Three: There is an affirmative association between past orientation and impulse buying behavior.

\section{Research Methodology}

Quantitative research tool is engaged for this research for reasons of reliability validity of the results unlike in qualitative where there is a lot of bias in terms of the results. Quantitative research allows researchers to provide statistical facts and estimates about relationships between constructs of research interest and to make a sweeping statement of extrapolations on the defined target population. Quantitative research is fast and can be conducted on large numbers of respondents with little cost and effort. Consumers around Gauteng province were the target population for easy accessibility and distribution of questionnaires. This would also cut transport cost. 350 respondents were targeted because the bigger the data set the more reliable and valid the results using a convenience sampling method.

Presentation of the Results: Table 1, more females plays a part in the study than males. This may be that female, buy more compulsively than men because in general women love fashion (Retief, Erasmus and Petzer 2018). Ages ranging from 23 to 35 are more active because that's the working class group in which they just buy to please their partners and to look good and unique at work. Single people buy more impulsively than others because they do not have dependents like married people and they are still looking for the right partners. Table 1 also shows that blacks buy more impulsively without thinking twice unlike whites people who in most cases think before they purchase anything. According to the study results, white people have the tendency to invest and save, unlike black people who are not as much interested to invest and save. White people believe so much in investing and saving unlike the black people who do not think about tomorrow when purchasing. Those who speak Zulu act in an impulsive way when purchasing compared to others because Zulu people love fashion to attract the opposite sex.

Table 1: Sample Demographic Characteristics

\begin{tabular}{lll}
\hline Gender & Frequency & Percentage \\
\hline Male & 96 & $27.4 \%$ \\
Female & 254 & $72.6 \%$ \\
Total & $\mathbf{3 5 0}$ & $\mathbf{1 0 0 \%}$ \\
Age & Frequency & Percentage \\
$18-22$ & 61 & $17.4 \%$ \\
$23-35$ & 170 & $48.6 \%$ \\
$35-60$ & 119 & $34.0 \%$ \\
Total & $\mathbf{3 5 0}$ & $\mathbf{1 0 0 \%}$ \\
$\quad$ Marital Status & Frequency & Percentage \\
Married & 80 & $22.9 \%$ \\
Single & 155 & $44.3 \%$ \\
Divorced & 101 & $28.9 \%$ \\
Widowed & 14 & $4.0 \%$ \\
Total & $\mathbf{3 5 0}$ & $\mathbf{1 0 0 \%}$ \\
& & \\
Race & Frequency & Percentage \\
Blacks & 239 & $68.3 \%$ \\
Whites & & \\
Coloureds & 106 & $30.3 \%$ \\
Total & 5 & $1.4 \%$ \\
& $\mathbf{3 5 0}$ & $\mathbf{1 0 0 \%}$ \\
Language & & \\
English & Frequency & Percentage \\
\hline
\end{tabular}




\begin{tabular}{lll}
\hline Afrikaans & 61 & 13.7 \\
Zulu & 143 & $40.9 \%$ \\
Xhosa & 23 & 6.6 \\
South Sotho & 68 & $19.4 \%$ \\
Northern Sotho & 7 & $2.0 \%$ \\
Total & $\mathbf{3 5 0}$ & $100 \%$ \\
\hline
\end{tabular}

Source: Own source

Measurement Items: Slight variations made in order to fit the current research context and purpose. Fivequestionnaire scales which were adapted from the previous works of Donthu and Gilliland (2010) were used to measure uniqueness. Question asked of the participants was: "I like to take chances". Five items were taken from Clemes, Gan and Zhang, (2014) to measure how price impact on impulse buying. Sample question asked of the participants were: "Low prices allow me to save money as I buy branded goods". Another five-item scale taken from Karande and Merchant (2012) was utilized to determine the extent to which past-oriented consumers react towards acting impulsively. Sample questions asked of the participants were: "It gives me pleasure to think about my past". Moreover, the five-item scale taken from Xiao (2012) was used to determine compulsive buying behavior. Item query asked of the participants was: "I always buy something I had not planned to purchase".

Table 2: Analysis Statistics

\begin{tabular}{|c|c|c|c|}
\hline Research & Cronbach's Test & C.R Value & Factor loading \\
\hline
\end{tabular}

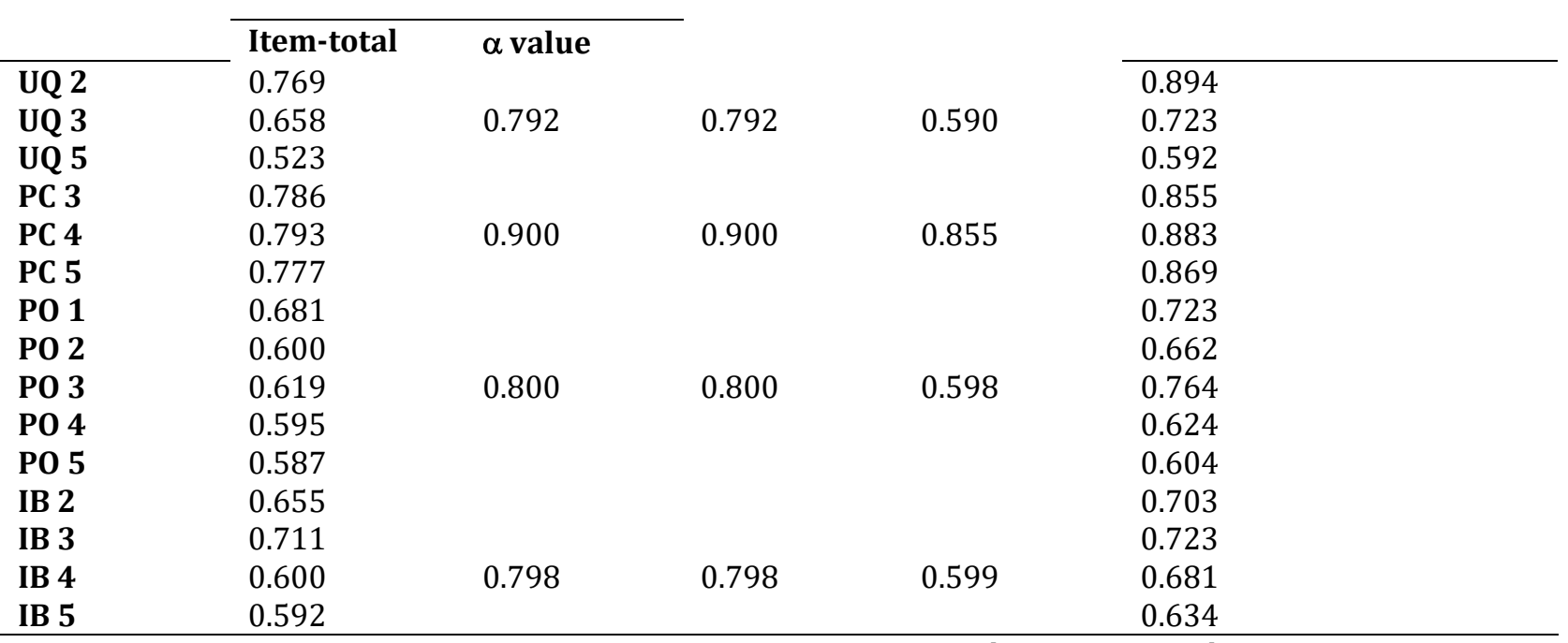

Note: C.R.: UQ: Uniqueness, PO: Past Orientation, PC: Price, IB: Impulsive Buying Behaviour, CR: Composite Reliability; AVE: Average Variance Extracted; S.V.: Shared Variance;* Scores: 1 - Strongly Disagree; 3 Neutral; 5 - Strongly Agree

Source: Own source

Convergent validity is a technique to assess construct validity (Goddard \& Melville 2010; Graziano \& Raulin 2010). In the current study, convergent validity was determined through the item to total correlation and factor loading. Item to total correlation and factor loading were assessed using SPSS. For consistency to assess the items, factor loading should be greater than 0.5 (Fornell \& Larcker 1981). As seen in Table 2, the factor loading of all the measurement instruments is within the range of 0.592 to 0.894 . All the items are greater than 0.5. These results mean that all the items are acceptable and that there is a relationship between each construct and each item. UQ 1, UQ 4, PC 1, PC 2 and IB 1 were deleted because the factor loadings were lower than 0.5 which is the threshold recommended by Anderson and Gerbing (1988). To evaluate the internal consistency of the research constructs, composite reliability was conducted in this study. 
The following formula was used to calculate composite reliability.

(CR): $\mathrm{CR} \eta=\left(\sum \lambda \mathrm{yi}\right) 2 /\left[\left(\sum \lambda \mathrm{yi}\right) 2+\left(\sum \varepsilon \mathrm{i}\right)\right]$

$\mathrm{CR}=$ (square of the summation of the factor loadings)/ [(square of the summation of the factor loadings) + (summation of error variances)]. Hair, Babin, Anderson and Tatham (2010) postulated that a CR greater than 0.7 reflects a good consistency of the variable. As shown in Table 1, all the four constructs in this study were having composite reliability between 0.792 and 0.900 (more than 0.700 ). Therefore, these results prove the existence of good internal reliability of the constructs in this study. Chin (1998) argued that the AVE of the research constructs should be greater than 0.5. The AVE was calculated by using the following formula of Fornell and Lacker (1981):

$\mathrm{V} \eta=\sum \lambda \mathrm{yi} 2 /\left(\sum \lambda \mathrm{yi} 2+\sum \varepsilon \mathrm{i}\right)$

$A V E=$ summation of the square of factor loadings / [(summation of the square of factor loadings) + (summation of error variances)]. The values of AVE of the research constructs are between 0.590 and 0.855 (as presented in Table 2); these values exceed the recommended threshold of 0.50 (Fornell \& Larcker 1981). Therefore, these results are acceptable. After endorsing the reliability and validity of the measurement instruments (reported in Table 2), the study progressed to test the proposed hypotheses. In total, there are three hypotheses that are tested.

Figure 2 provides the proposed hypotheses and the respective path coefficients. The same results of the path coefficients are tabulated in Table 3 depicting the item to total correlations, AVE, CR and factor loadings. The convenience sampling technique was chosen because it was quick and cheap, also because respondents were conveniently available (Creswell, Ebersohn, Eloff, Ferreira, Ivankova, Jansen, Nieuwenhuis, Pietersen, Plano Clark \& Van Der Westhuizen, 2012).

Path Model Results and Factor Loadings: Path modelling results and as well as the item loadings for the research constructs are shown in figure 2. In the figure, UQ stands for Uniqueness; PO is the acronym for Past Orientation; PC stands for Price and IB represents Impulsive Buying Behaviour.

Figure 2: SMART PLS Figure

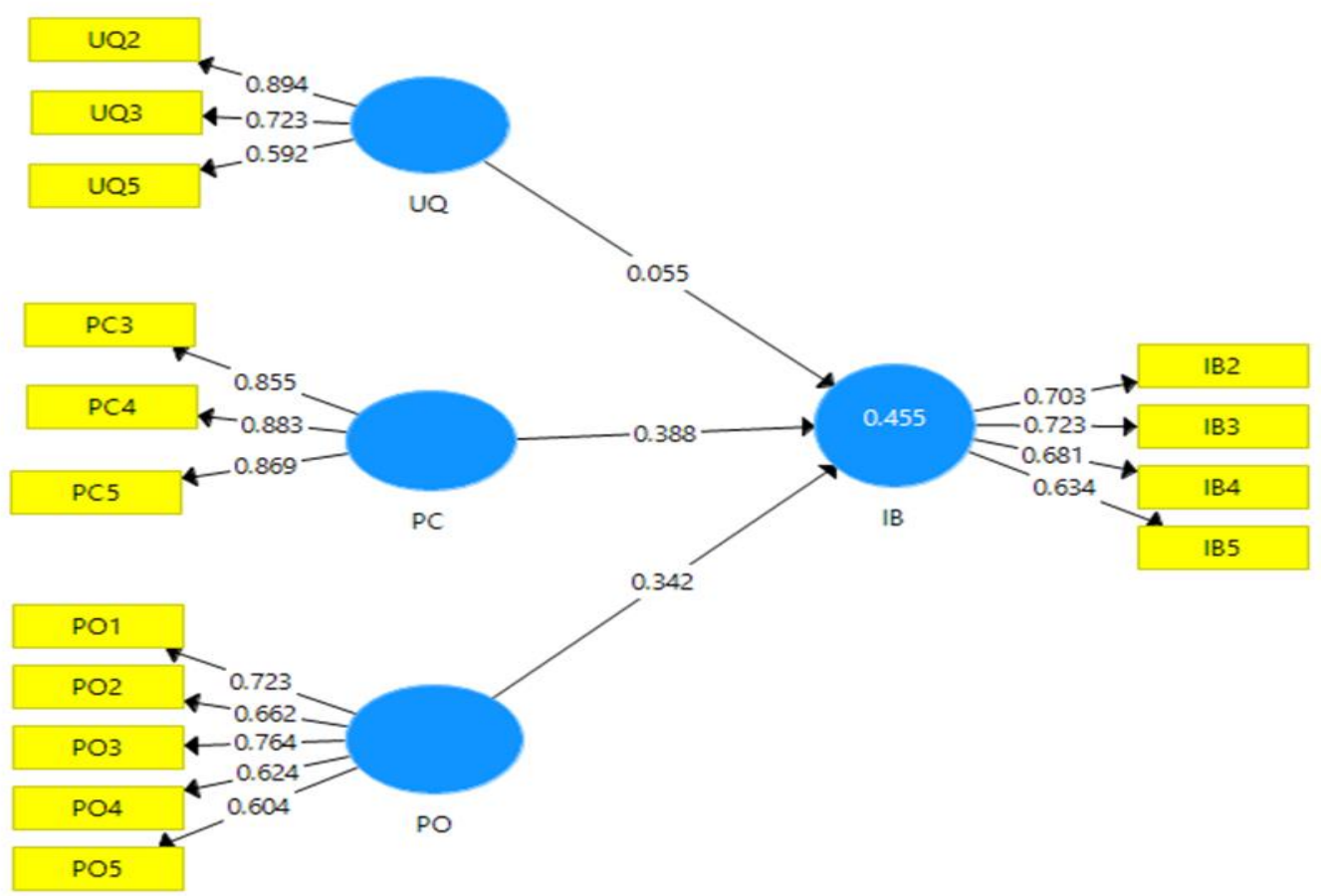

Source: Own Source 
In the current study, Table 3 and 4 show a positive significant correlation between the different constructs. The correlation between PC and IB has a value of $(\mathrm{r}=0.595 ; \mathrm{p}<0.01)$. Moreover, the correlation matrix describes a positive relationship between PO and IB with a value of $(\mathrm{r}=0.580 ;<0.01)$ as well PO and PC with a value of $(r=0.523 ; p<0.01)$. Furthermore, the same type of correlation exists between UQ and IB $(r=0.472$; $\mathrm{p}<0.01)$; $\mathrm{UQ}$ and $\mathrm{PC}(\mathrm{r}=0.511 ; \mathrm{p}<0.01)$ as well as $\mathrm{UQ}$ and $\mathrm{PO}(\mathrm{r}=0.598 ; \mathrm{p}<0.01)$.

Table 3: Correlations between Constructs

\begin{tabular}{lllll}
\hline Research Construct & \multicolumn{2}{l}{ Construct correlation } & \\
& IB & PC & PO & UQ \\
\hline Impulsive Buying Behavior (IB) & 1.000 & & & \\
Price (PC) & $0.595^{* *}$ & 1.000 & & \\
Past Orientation (PO) & $0.580^{* *}$ & $0.523^{* *}$ & 1.000 & \\
Uniqueness (UQ) & $0.472^{* * *}$ & $0.511^{* *}$ & $0.598^{* *}$ & 1.000 \\
${ }^{* *}$ Association is significant at the 0.01 level (2-tailed) & & \\
\hline
\end{tabular}

Source: Own source

Table 4: Hypothesized Relationships and Path Co-efficiency Proposed Hypothesis Relationship Hypothesis Path Coefficient Decision

\begin{tabular}{llll} 
& \multicolumn{3}{l}{ Estimates } \\
Need for Uniqueness $\rightarrow$ Impulsive Buying Behavior & H1 & $0.055^{* * *}$ & Accepted
\end{tabular}

Price $\rightarrow$ Impulsive Buying Behavior $\quad$ H2 $\quad 0.388^{* * *} \quad$ Accepted

Past Orientation $\rightarrow$ Impulsive Buying Behavior $\quad$ H3 $\quad 0.342^{* * *} \quad$ Accepted

${ }^{* * *}$-value $<0.001,{ }^{* *}$ p-value $<0.05,{ }^{*}$ p-value $<0.1$; using a significance level of 0.05 , critical ratios (t-value) that exceed 1.96 would be significant.

Source: Own source

\section{Interpretation of the Results}

The following section discusses the result of hypotheses that are indicated in Table 4 .

(H1): The first hypothesis (H1) in this study stated that requisite for uniqueness significantly impact on impulsive buying behaviour. The path coefficient of 0.055 indicates a very strong relationship between uniqueness and compulsive buying behaviour. Thus, the $\mathrm{p}$-value is significant at $99 \%$ ( $\mathrm{r}=0.001$ ), which means that this hypothesis is supportive and significant. This is supported by the study done by Islam, Wei, Sheikh, Hameed and Azam (2017) which shows that people need to look different and unique by increasing the level of materialism thereby leading to self-actualisation and compulsive buying behaviour.

(H2): With reference to the second hypothesis (H2), the study hypothesized that price significantly influenced impulsive buying behavior. Table 4 indicates a path coefficient value of $(\mathrm{r}=0.388)$ with $(\mathrm{p}<0.001)$ for $\mathrm{H} 2$; the results are significant and confident at $99 \%$. The path coefficient endorses the presence of a reasonable relationship between price and impulsive buying behavior. This concurred with the results found by Surulivel, Selvabaskar, Nigama, Rafic and Pradeepa (2018) and Ayub and Zafar (2018) that the issue of price attracts people to act in an impulsive way. Sales promotions which include free vouchers, refunds, free sampling, competition and gift packs effect impulsive buying. Price discount offers which include price and bulk discounts have a major effect on consumer towards a brand. Price discounts increase sales and also stimulate impulsive buying (Ayub \& Zafar 2018)

(H3): A positive correlation was hypothesized between past orientation and impulsive buying behaviour. After tested H3, a path coefficient of $(\mathrm{r}=0.342)$ was obtained. The result confirms a positive relationship between past orientation and spontaneous buying behaviour. The relationship between these two constructs is highly significant at $99 \%$ indicated by a $(\mathrm{p}<0.001)$. The results confirm or validate the existence of the 
relationship. Also, the study by Liang (2012) and Raisanen et al. (2018) proves that past orientation has an effect on impulsive buying.

\section{Recommendations of the Study}

The first major practical input of this research is that it provides much needed empirical data on impulsive buying, what consumers do most of the time and with what in mind. This research will help consumers to know more about impulsive buying and to help them be vigilant when purchasing so as not to indulge in buying impulsively as it can lead to disastrous effects like being penniless and divorce in marriages (Islam et al., 2017; Ave, Venter \& Mhlophe 2015). Hypothesis two which is the relationship between price and impulsive buying behaviour has the highest path-coefficient on 0.388 which shows that buyers should focus more on the issue of price as it is the major culprit that allure them to just buy without proper planning. Nevertheless, the price also is a contributing factor. A number of people go for impulsive purchasing just due to the reason it was on discount. Temptations like stock clearances or offers for a premium to customers also promote impulsive buying. It is the responsibility of consumers not to be tempted by catchy advertisements. The consumers should know when and how to purchase, for example, the consumer should make a shopping list before going on shopping.

However, since impulse purchase occurs subconsciously, on the spur of movement, a significant portion of those shoppers carrying shopping list also fail to abstain from impulse purchase though they show lower impulse purchase behaviour. On the theoretical contributions, the study contributes immense knowledge to the consumers to practice the consumer buying process instead of just following the impulsive buying process. This will help consumers not acting impulsively when purchasing products proper planning is needed. The consumer buying procedure begins with problem recognition, followed by information search, pre-purchase alternative evaluation, then the purchase and lastly, the post-purchase evaluation (Dhurup \& Tisiime 2011: 519). This will help the consumers that buying impulsively it's an issue and a risk to take. The model also is very robust and contributes to the extant literature on the subject matter.

Impulsive buying can be correlated to unhappiness and anxiety and is required to be controlled from a psychological perspective. "Impulsive buying tendency can be linked to personality trait which triggers a person making the impulsive purchase a habit. Impulsive buyers are mainly social beings who are very much concerned about their social image and status. In order to impress others and to look good so that others feel positive about them, they opt to impulsive buying" (Dhurup \& Tisiime 2011: 522). To lighten their mood buyers, buy in an impulsive manner. Impulsive buyers are not much concerned about the results of their spending pattern. "As proved, only individuals with low self-control easily enter into impulse buying behavior (Chen \& Yao 2018:1249). Consumers need to control themselves physiologically by avoiding buying impulsively. In addition, customers will feel the urge to buy "limited edition" products to fulfil their esteems (Graciola et al., 2018:202). There is no need to buy things which you have not planned for since it will lead to bankruptcy and other problems like health risks (Ayub \& Zafar 2018).

Limitations and Conclusion of the Study: The study did not focus on time orientation and preparation as antecedents of impulsive buying behavior. This network can be expanded to include other variables such as regulatory focus, need for stimulation, and store/brand loyalty. This study focus on consumers in South Africa only but a comparison study could yield more robust results and it could be very beneficial to see what other countries experience on impulsive buying behavior. This will be beneficial to the world in general because most authors agree that impulsive buying it's a world problem (Baumeister 2014: Chen \& Yao 2018; Zhang et al., 2018).

Therefore, it can be concluded that a substantial portion of all consumer retail purchases are impulsive and retailers cannot afford to overlook the contribution of revenue generated through impulse purchases. This behaviour may well curtail from several different causes that include broad personality characteristics, as well as specific short-term states and environmental stimuli. The correlation of the basic personality factors and the specific stimuli that trigger specific incidents of impulse buying seemed both reasonable and valuable and is worthy of further study. 


\section{References}

Aaker, J. L. (2013). Dimensions of Brand Personality. Journal of Marketing Research, 34(3), 347-356.

Amaldoos, W. \& Jain, S. (2005). Pricing of conspicuous goods: a competitive analysis of social effects. Journal of Marketing, 42, 30-42.

Anderson, J. C. \& Gerbing, D. W. (1988). Structural equation modelling in practice: a review and recommended two-step approach. Psychological Bulletin, 103(3), 411-423.

Ave, D. S., Venter, M. \& Mhlophe, B. (2015). Sensory branding and buying behaviour in coffee shops: A study on Generation Y. The Retail and Marketing Review, 11(2), 93-110.

Ayub, R. \& Zafar, M. (2018). External Stimuli and impulsive buying behaviour. Market Forces, X111(1), 70-89.

Babbie, E. R. (2010). The Practice of Social Research. Twelfth edition. Belmont, California: Wadsworth Cengage.

Bakewell, C. \& Mitchell, V. W. (2009). Male consumer decision-making styles. International Review of Retail, Distribution and Consumer Research, 14(2), 223-240.

Baumeister, R. F. (2014). Yielding to Temptation: Self-Control Failure, Impulsive Purchasing, and Consumer Behavior. Journal of Consumer Research 28(4), 670-676.

Belk, R. W. \& Malhotra, N. K. (2013). Self-Concept and Product Choice: An Integrated Perspective. Journal of Economic Psychology, 9(1), 1-28.

Bharwada, C. (2010). Loyalty and customers: Impulse buying boosting your bottom line. Journal of Consumer Goods and Marketing, 9(33), 9-14.

Burgess, A. C. B. (2003). Gender differences in cognitive and affective impulsive buying. Journal of Fashion Marketing and Management: An International Journal, 7(3), 282-295.

Burns, D. \& Homer, W. (2014). Need for uniqueness: Shopping mall preference and choice activity. International Journal of Retail and Distribution Management, 23(12), 4-12.

Burns, N. \& Grove, S. K. (2009). The Practice of Nursing Research: Appraisal, Synthesis, and Generation of Evidence. St. Louis: Saunders Elsevier.

Chebad, J. C., Michon, R., Haj-Salem, N. \& Oliveira, S. (2014). The effects of mall renovation on shopping values, satisfaction and spending behavior. Journal of Retailing and Consumer Services, 21, 610-618.

Chen, C. C. \& Yao, J. Y. (2018). What drives impulsive buying behaviors in a mobile auction? The perspective of the Stimulus-Organism-Response model. Telematics and Informatics, 35, 1249-1262.

Chin, W. W. (1998). The partial least squares approach to structural equation modelling. Modern Methods for Business Research, 295 (2), 295-336.

Clemes, D. M., Gan, C. \& Zhang, J. (2014). An empirical analysis of online shopping adoption in Beijing, China. Journal of Retailing and Consumer Services, 21, 364-375.

Cotte, J., Ratneshwar, S. \& Mick, D. G. (2012). The time of their lives: Phenomenological and metaphorical characteristics of consumer time style. Journal of Consumer Research, 31(2), 333-345.

Creswell, J. w., Ebersohn, L., Eloff, I., Ferreira, R., Ivankova, N. v., Jansen, J. d., Nieuwenhuis, J., Pietersen, J., Plano Clark, Vl. \& Van De Westhuizen, C. (2012). 11th ed. First Steps in Research. Van Shaik Publisher: Pretoria.

Dittmar, H. B. J. (2005). Gender identity and material symbols: Objects and decision considerations in impulse purchases. Journal of Economic Psychology, 16, 491-511.

Donthu, N. \& Gilliland, D. J. (2010). The infomercial shopper. Journal of Advertising Research, 36(2), 69-76.

Dhurup, M. \& Tusiime, R. (2011). Impulsive buying behavior of apparel merchandise among university students in Southern Gauteng. Journal of Contemporary Management, 8, 517-539.

Fisher, R. J. \& Price, L. L. (2014). An investigation into the social context of early adoption behavior. Journal of Consumer Research, 19, 477-486.

Fornell, C. \& Larcker, D. F. (1981). Structural equation models with unobservable variables and measurement error. Journal of Marketing Research, 18(1), 39-50.

Goddard, W. \& Melville, S. (2010). Research Methodology: An Introduction. Second edition. Lonsdowne: Juta \& Co, Ltd.

Goldsmith, R. E., Clark, R. A. \& Goldsmith, E. B. (2006). Extending the psychological profile of market mavenism. Journal of Consumer Behavior, 5(5), 411-420.

Graziano, Am. \& Raulin, M. C. (2010). Research Methods: A Process of Enquiry. Seventh edition. Boston: Pearson Education, Inc. 
Graciola, A. P., Toni, D. D., Lima, V. Z. \& Milan, G. S. (2018). Does price sensitivity and price level influence store price image and repurchase intention in retail markets? Journal of Retailing and Consumer Services, 44, 201-213.

Gwinner, K. P. \& Eaton, J. (2012). Building brand image through event sponsorship: The role of image transfer. Journal of Advertising, 38(4), 47-57.

Hair, J. F., Babin, B. J., Anderson, R. E. \& Tatham, R. L. (2010). Multivariate Data Analysis. A Global Perspective. $7^{\text {th }}$ ed. Prentice-Hall: London.

Hoch, S. I. \& Loewenstein, G. F. (2016). Time - inconsistent preferences and consumer self-control. Journal of Consumer Research, 17(4), 492-508.

Hodgins, D. C. \& Amy, E. (2009). Future time perspective in pathological gamblers. Journal of Nervous and Mental Disease, 190(11), 775-780.

Holbrook, M. B. (2012). Nostalgia and consumption preferences: Some emerging patterns of consumer tastes. Journal of Consumer Research, 20, 245-256.

Huang, J. S. \& Chen, X. (2013). The effect of consumer's purchase plan on reference price choice. African Journal of Business Management, 7(6), 424-431.

Huang, W. H. \& Kuai, L. (2006). Short communication. Journal of Air Transport Management, 12, 207-211.

Islam, T., Wei, J., Sheikh, Z., Hameed, Z. \& Azam, R. I. (2017). Determinants of compulsive buying behavior among young adults: The mediating role of materialism. Journal of Adolescence, 61, 117-130.

Janakiraman, N., Meyer, R. J. \& Morales, A. C. (2006). Spillover effects: How consumers respond to unexpected changes in price and quality. Journal of Consumer Behaviour, 33, 361-69.

Jaehyeon, J. \& Jaehyeon, A. (2016). The effect of social and ambient factors on impulsive purchasing behavior in social commerce. Journal of Organizational Computing and Electronic Commerce, 26(4), 285-306.

Kacen, J. J. \& Lee, J. A. (2016). The influence of culture on consumer impulsive buying behaviour. Journal Consumer Psychology, 12(2), 31-40.

Karande, K. \& Merchant, A. (2012). The impact of time and planning orientation on an individual's recreational shopper identity and shopping behavior. Journal of Marketing Theory and Practice, 20(1), 59-72.

Kim, H. M. \& Kramer, T. (2006). The effect of novel discount presentation on consumers' deal perceptions. Marketing Letters, 17, 311-321.

Knight. M. \& Kim, E. Y. (2007). Japanese consumers' need for uniqueness: Effects on brand perceptions and Purchase Intention. Journal of Fashion Marketing and Management, 11(2), 270-280.

Kron. J. (2014). Home-Psychology: The social psychology of home and decoration. New York: Potter.

Lang, C. \& Armstrong, C. M. J. (2018). Collaborative consumption: The influence of fashion leadership, need for uniqueness and materialism on female consumers' adoption of clothing renting and swamping. Sustainable Production and Consumption, 13, 37-47.

Lee, Y., Ho, F. N. \& Wu, M. C. (2018). How do form and functional newness affect adoption preference? The moderating role of consumer need for uniqueness. Journal of Consumer Marketing, 35(1), 79-90.

Liang, Y. P. (2012). The relationship between consumer product involvement, product knowledge and impulsive buying behavior. Procedia-Social and Behavioral Sciences, 57, 325-330.

Lindblom, A., Lindblom, T. \& Wechtler, H. (2018). Collaborative consumption as C2C trading: Analyzing the effects of materialism and price consciousness. Journal of Retail and Consumer Services, 44, 244-252.

Loureiro, S. M. S. \& Breazeale, M. (2016). Pressing the Buy Button: Generation Y's Online Clothing Shopping Orientation and Its Impact on Purchase. Clothing and Textiles Journal, 34(3), 163-178.

Mattila, A. S. \& Wirtz, J. (2008). The role of pre-consumption effect in post-purchase evaluation of services. Psychology \& Marketing, 17(7), 587-605.

Mcinnes, W. \& Price, H. (2012). A conceptual approach to marketing. Journal of Marketing Research, 31, 473479.

Millman, R. E. (2006). Using background music to affect the behavior of supermarket shoppers. Journal of Marketing, 46(3), 86-91.

Netemeyer, R. G., Krishnan, B., Pulling, C., Wang, G., Yagci, M., Dean, D. \& Wirth, F. (2015). Developing and Validating measures of facets of customer-based brand equity. Journal of Business Research, 57, 209-224.

Park, J. H. \& Park, J. W. (2015). The effect of experience in the A380 duty-free showcase on customer behaviors. Journal of Air Transport Management, 47, 135-141.

Park, E. J., Kim, E. Y. \& Forney, J. C. (2017). A structural model of fashion-oriented impulsive buying behavior. Journal of Marketing, 10(4), 433-446. 
Puri. R. (2012). Measuring and modifying consumer impulsiveness: A cost-benefit accessibility framework. Journal of Consumer Psychology, 5(2), 87-113.

Raisanen, H. K., Bjork, P., Lonnstrom, A. \& Jauffret, M. N. (2018). How consumers' need for uniqueness, selfmonitoring and social identity affect their choices when luxury brands visually shout versus whisper. Journal of Business Research, 84, 72-81.

Raju, P. S. (2012). Optimum Stimulation Level: It's Relationship to Personality, Demographics and Exploratory Behaviour. Journal of Consumer Research, 7, 272-282.

Retif, M. M., Erasmus, A. C. \& Petzer, D. J. (2018). Exploring the internal antecedents that prompt consumers' impulsive behavior in experiential retail contexts. Acta Commercii, 18(1), 1-12.

Rook, D. W. \& Hoch. S. J. (2012). Consuming impulses. Advances in Consumer Research, 12, 23-27.

Rook, D. W. \& Fisher, S. (2016). The Buying Impulse. Journal of Consumer Research, 14, 189-199.

Rootman, C. \& Kruger, J. (2017). Buying behavior in the South African clothing retail industry: considering reference groups and culture. Journal of Contemporary Management, 14, 1035-1063.

Schindler, R. M. (2012). Pricing Strategies: A Marketing Approach. Thousand Oaks, California: SAGE.

Sherry, J. F. (2012). A sociocultural analysis of a Midwestern American flea market. Journal of Consumer Research, 17(1), 13-30.

Steenkamp, J. M., Batra, R. \& Alden, D. L. (2015). How perceived brand globalness creates brand value. Journal of International Business Studies, 34(1), 53-65.

Stern, H. (1962). The significance of impulsive buying today. Journal of Marketing, 26(2), 59-62.

Sunil, A. \& Kesari, B. (2017). Impulsive buying: A Consumer Trait Prospective in Context of Central India, Global Business Review, 19(2), 477-493.

Sunil, A. \& Kesari, B. (2018). Role of consumer traits and situational factors on impulsive buying: does gender matter? International Journal of Retail and Distribution Management, 46(4), 386-405.

Surilivel, S. T., Selvabaskar, S., Nigama, K., Rafic, M. \& Pradeepa, S. (2018). Shopping Emotions and Risk

Associated in Impulsive Purchasing Behaviour. International Journal of Pure and Applied Mathematics, 119(7), 2357-2389.

Syam, N. B., Ruan, R. \& Hess, J. D. (2005). Customized Products: A Competitive Analysis. Marketing Science, 24(4), 569-584.

Tendai, F. \& Crispen, C. (2009). In-store shopping environment and impulsive buying. African Journal of Marketing Management, 1(4), 102-108.

Thoumrungroje, A. (2018). A Cross-National Study of Consumer Spending Behaviour: The Impact of Social Media Intensity and Materialism. Journal of International Consumer Marketing, 1(2), 5-25.

Tian, K. T., Bearden, W. O. \& Hunter, G. L. (2011). Consumers' need for uniqueness: scale development and validation. Journal of Consumer Research, 28(1), 50-66.

Venter De Villiers, M., Chinomona, R. \& Chuchu, T. (2018). The influence of store environment on brand attitude, brand experience and purchase intention. South African Journal of Business Management, 49(1), 1-8.

Watson, D., Clark, L. A. \& Tellegen, A. (2012). Development and validation of brief measures of positive and negative affect. Journal of Perspective Social Psychology, 54(6), 1063-1070.

Weinberg, P. \& Gottwald, W. (2012). Impulsive consumer buying as a result of emotions. Journal of Business Research, 10(1), 43-57.

WU, P. T. \& LEE, C. J. (2016). Impulse buying behavior in cosmetics marketing activities. Total Quality Management and Business Excellence, 27(10), 1091-1111.

Xiao, X. (2012). The influence of consumer's intrinsic motivation and external stimulus on the impulse buying, satisfaction, repurchase intention and word of mouth. Journal of Air Transport Management, 47, 135-141.

Yanga, D., Zhaob, P., Louc, R. \& Weia, H. (2013). Environmental marketing strategy effects on market-based assets. Total Quality Management \& Business Excellence, 24(6), 707-718.

Zeithaml, V. A., Berry, L. L. \& Parasuraman, A. (2015). The behavioral consequences of service quality. Journal of Marketing, 60(2), 31-46.

Zhang, B. \& Kim, J. H. (2013). Luxury fashion consumption in China: Factors affecting attitude and purchase intent. Journal of Retailing and Consumer Services, 20, 68-79.

Zhang, K. Z. K., Xu, H., Zhao, S. \& Yu. (2018). Online Reviews and impulsive buying behavior: the role of browsing and impulsiveness. Internet Research, 28(3), 522-543.

Zimbardo, P. G. \& John, N. B. (2008). Putting time in perspective: A valid, reliable individual-differences metric. Journal of Personality and Social Psychology, 77(6), 1271-1288. 